\title{
Peter and Fevronia and the Day of Family, Love, and Fidelity: Pronatalism and Unstable Gender Order in Contemporary Russia
}

DOI: https://doi.org/10.22394/2311-3448-2018-5-2-23-43

Diana Dukhanova - Department of Modern Languages at the College of the Holy Cross in Worcester, Massachusetts (USA). diana dukhanova@brown.edu

This paper investigates the role of the Day of Family, Love, and Fidelity in the deployment of Russian state family policy since 2006. It argues that the holiday is emblematic of a cooperative, rather than synchronous, relationship between church and state in the promotion of pronatalism and so-called "traditional family values," and highlights the ways in which public discourse around the holiday intentionally obscures internal contradictions within the dominant family ideologies of both institutions. Investigating these contradictions, the paper analyzes the manner in which the state deploys a selective segment of the church's teachings on marriage, gender, and the family to bolster the official pronatalist agenda while rejecting the church's most conservative solutions to demographic decline, such as an abortion ban. Most importantly, the paper examines the problematic nature of the deployment of the hagiography of Peter and Fevronia - the basis for the Day of Family - to pronatalist ends, arguing that the clash between the ideal of family life portrayed in the hagiography and the goals of the holiday now celebrated in the saints' honor points to a larger incompatibility between Orthodox matrimonial theology and the politicized promotion of reproduction.

Keywords: pronatalism, Russian Orthodox Church, gender, sexuality, hagiography, family policy, demographic decline, Vladimir Putin.

\section{Introduction}

N July 8, 2008 - the "Year of the Family" - Russia celebrated the nationwide Day of Family, Love, and Fidelity for the first time. The fanfare surrounding the holiday, including public events in all major urban areas with ceremonies and awards honoring 
Russian families, has grown and increased in visibility every year since its inception. However, the ideological goals of the celebration - the strengthening of the family through lower divorce rates, increased birthrates, and the restoration of gender-based hierarchy - remain unmet.

This paper investigates the role of the Day of Family, Love, and Fidelity in the deployment of Russian state family policy since 2006, arguing that the holiday is emblematic of a cooperative, but not synchronous, relationship between church and state in the promotion of pronatalism and so-called Russian family values, and highlights the ways in which the public discourse of the holiday intentionally obscures internal contradictions within the dominant familial ideologies of both institutions. Further, the paper analyzes the manner in which the state attempts to deploy a selective segment of the church's teachings on marriage, gender, and the family to bolster the official pronatalist agenda while rejecting the church's most conservative solutions to demographic decline, such as an abortion ban. Most importantly, the paper examines the problematic nature of the deployment of the hagiography of Peter and Fevronia - the basis for the Day of Family - to pronatalist ends, arguing that the clash between the ideal of family life portrayed in the hagiography and the goals of the holiday now celebrated in the saints' honor points to a larger incompatibility between Orthodox matrimonial theology and the politicized promotion of reproduction. The ideal that the holiday promotes - the heteronormative, monogamous Russian Orthodox family with many children - relies on the promotion of a putatively traditional gender order that is not reflected either in concrete state family policy focused largely on mother and child, or in the ascetic Orthodox theology of marriage. This theology, taught to the core faithful, is currently obscured by church leadership, which has seized upon the Day of Family in an effort to disseminate socially conservative ideals and has demonstrated a willingness to obscure substantive church teachings to serve pronatalist ends.

\section{Peter and Fevronia of Murom}

The Day of Family, Love, and Fidelity is a somewhat secularized version of the Russian Orthodox saints' day of Peter and Fevronia of Murom, celebrated on July 8 . There is a major discrepancy between the 16thcentury hagiographic ${ }^{1}$ portrayal of the holiday's honored saints and the

1. The original hagiography of the saints and the narrative referred to here, The Tale of Peter and Fevronia of Murom (Povest'o Petre i Fevronii Muromskikh), was composed 
matrimonial and gender-based ideals that they are called upon to represent in the context of the Day of Family. The tale of the married saints thought to be based on a 13th-century Murom prince and a peasant girl he married according to legend - certainly represents love and fidelity, but does not offer an image of the ideal Orthodox family as it is conceptualized in the rhetoric and visual discourse of the holiday.

While Peter and Fevronia have been chosen as the figureheads of the Russian family as it is conceptualized in the contemporary rhetoric of "traditional values," the key feature of the traditional family insofar as the ideology of the holiday is concerned - children - is missing from their story, highlighting the inherent problem in conceptualizing the church as an uncritical pronatalist voice. While the church certainly amplifies teachings that extol the virtues of reproduction - teachings that often emphasize directly the same demographic concerns around the decline of the Russian population that occupy the architects of state family policy - the substance of the theology of matrimony de-emphasizes reproduction as its central goal. The Day of Family encapsulates a long-standing historical tension surrounding matrimonial theology vis-à-vis childbearing within the Russian Orthodox Church, and represents an effort to de-emphasize the ascetic underpinnings of that theology in favor of winning a perceived battle against both demographic decline and Western cultural imperialism.

Let us pause here to take a closer look at the hagiography at the center of the holiday. Lyobomira Parpulova Gribble (1995) argues that The Tale of Peter and Fevronia is an "apologia" for the Orthodox ecclesiastical model of marriage. Indeed, it is the clearest statement of matrimonial theology available in the corpus of Russian Orthodox literature to this day, which accounts for the deployment of Peter and Fevronia to bolster a familial ideal divergent from their narrative. The tale emphasizes not fecundity or familial hierarchy but monogamous, sacrificial spousal love as the goal of the Orthodox marriage, and Peter and Fevronia are largely portrayed as equals. Indeed, it is Fevronia who might be said to take the lead; as a peasant maiden, she secures the promise of marriage from the prince in return for healing him from leprosy. Later, when Peter's boyars balk at a peasant princess and demand their divorce, he re-

by Hermolaus-Erasmus (Ermolai Pregreshnii), an archpriest (later monk) and writer in the 16th century (Demkova 1997). Some scholars, most prominently Dmitrii Likhachev, argue that the written story of Peter and Fevronia precedes Hermolaus-Erasmus. The assertion is based on a recorded church service from the 15th century that mentions the 13th-century Murom prince Pyotr and his wife named Fevronia, buried in the same place as per the hagiography. 
jects the throne and exiles himself with Fevronia until the boyars beg for their return in the face of widespread turmoil.

Although the tale concerns an aristocratic couple who should rightly be preoccupied with the production of an heir, such a goal is never mentioned, while "the desire of the spouses to stay together is placed at the very center of the plot" (Gribble 1995, 97). When Peter and Fevronia become monk and nun in old age and still find their way back to each other in the grave, they achieve the rare status of married monastics with a love that transcends the patriarchal gender order.

Peter and Fevronia's hagiography therefore serves the pronatalist ends of the Day of Family, Love, and Fidelity only when it is not carefully examined. The incongruity between the aims of the holiday and the narrative and message of the Tale of Peter and Fevronia is exacerbated by a contradictory approach to the implementation of pronatalist policy in terms of the state's putative support of "Orthodox family values."

\section{Establishing the Day of Family, Love, and Fidelity}

Murom municipal officials, who established a local Day of Family in 2001 amid a resurgence of the veneration of the saints, promoted the holiday as a "native" Russian alternative to the celebration of St. Valentine's Day, which has gained immense popularity in post-Soviet Russia and has come to be perceived as a tool of Western cultural imperialism resulting in the destruction of the family. In August of 2002, Murom held a conference of fifteen ancient Russian cities, including Vladimir, Staraya Lagoda, and Suzdal', all of which had banned the celebration of Valentine's Day, to discuss the promotion of the alternative holiday.

Indeed, fears of Valentine's Day as a tool of Western cultural imperialism have motivated many church and state officials in their promotion of the Day of Family since its inception, positioning the two holidays as symbolic of a struggle between Russia's traditional family values and the debauchery of the West. In 2011, for example, chairman of the Patriarchal Committee on Questions of Family, the Protection of Motherhood, and Childhood, ${ }^{2}$ Archpriest Dmitry Smirnov, declared on

2. This department was founded in 2011 in cooperation with former Children's Rights Commissioner P.A. Astakhov, and in 2012, Astakhov and Bishop Panteleimon, chairman of the Synodal Department of Charity and Social Service, signed an agreement of cooperation - another event marking the new era of church-state cooperation around the pronatalist agenda. As a result of this agreement, clergy participate in the Public Council (Obschestvennyi sovet) on the rights of the child and in regional forums and conferences on the same (Shirokov 124). 
the televised program Besedy s batiushkoi on TK-Spas that Valentine's Day, a Western "business project," attracts youths who have no feeling for their own (Russian) culture. Valentine's Day celebrates vliublennost' (amorousness), he told his audience, which is not the same thing as liubov', true Christian love. From the state side, in 2017, Duma deputy Vitaly Milonov stated in an interview with the radio program Govorit Moskva (Moscow speaking) that the government had a duty to promote the Day of Family, Love, and Fidelity as an antidote to Valentine's Day, which promotes completely immoral standards.

In 2006, Murom officials successfully petitioned the federal government to enshrine the holiday under the auspices of Svetlana Medvedeva's Fund for Sociocultural Initiatives. The celebration of the first Day of Family, Love, and Fidelity during the Year of the Family - a presidential initiative focused on providing a greater degree of financial support and resources for families and encouraging the growth of families - signified the intensification of Russian pronatalist policy. However, significant disagreements exist both within the government and within the church regarding the necessity, deployment, and makeup of pronatalist policy.

\section{Russian Orthodox Theology and State Family Policy: De- ployment and Contradiction}

During the celebration of the Day of Family in 2011, Russian Orthodox patriarch Kirill gave a sermon at the Marfo-Mariinsky Convent in Moscow in support of the holiday as a transformative force in contemporary Russian society. However, Kirill also articulated the church's unease about the state's lack of a full commitment to the success of the family as evidenced by the legality, accessibility, and widespread practice of abortion. Calling upon the state to fully commit to the demographic battle, the patriarch used his sermon to (unsuccessfully) call on the Duma to sign into law a bill that would remove mandatory state insurance (OMS) coverage for the procedure and push forward its prohibition. Appealing to the fears of pronatalist politicians, Patriarch Kirill warned of imminent human extinction. Calling widespread abortion and non-traditional families regrettable outcomes of the sexual revolution in the West, Kirill invoked the Russian government's responsibility to preserve "traditional family values," defined by compulsory heterosexuality and fecundity. Using the biggest platform accessible to the church for the dissemination of its message beyond the small minority of churchgoers, Kirill continues to pressure the state to follow its moral guidance in this area. 
Contemporary family policy is more in line with Russian Orthodox teachings surrounding reproduction than it has been at any other period in post-Soviet history. Although the decline of the family has been a concern since 1991, it was in the early 2000s, amid a widespread "alarmist mood" around falling birth rates, that demographic problems became a government priority (Chernova 2012, 79). Gradually, the church became a key agent in the promotion of state pronatalist policy, which centers on pronatalism within a far-reaching familial ideal that prioritizes young marriage, fecundity, monogamy, and the avoidance of divorce. As Michele Rivkin-Fish has observed, Russian pronatalism "aims to discipline women and men through a system of economic incentives and disincentives to fulfill the state's desires for increased fertility" by perceiving social behavior and attitudes as "ultimately malleable products of the right policy formula" (2010, 722). The state's "gender regime" relies heavily on economic and social incentives to promote and reinforce the ideal of the heteronormative fruitful family as the norm. However, as we will see, pronatalist policy is not internally coherent in terms of its dependence on conservative church principles and does not reflect the entirety or complexity of those theological principles or the Orthodox social norms upon which it draws.

The President's Address to the Federal Assembly on May 10, 2006, is commonly referred to in the relevant scholarship as "the pronatalist turn" in contemporary Russian history (Kim 2017, 66). It is in this speech that the president introduced the "maternity capital" program - referring to the provision of economic support to childbearing women to make up for their losses on the market - which constitutes the central component of Russian state family policy (Borozdina et al. 2016, 61). In January 2007, the new "maternity capital"3 entitlement for mothers giving birth to a second or third child went into effect. In his speech, Putin stated that increasing the number of mothers of many is achievable only if the financial impact of multiple pregnancies and maternity leaves is taken into account in pronatalist strategies, providing financial incentives to offset the economic hardship that a second child presents to the typical Russian family.

In keeping with the "pronatalist turn," after Putin's 2006 speech the Ministry of Health and Social Development significantly limited access to second-trimester abortions, requiring clinics to discourage

3. The entitlement provides a sum of 250,00o rubles (indexed to inflation) upon the child's third birthday and usable toward child care and education. 
the procedure and impose a forty-eight-hour waiting period. Additionally, in 2013, Putin signed into law a ban on the advertisement of abortion. Some movements toward a more conservative abortion policy have, thus, been made. However, bills aimed at further limiting access by removing the procedure from state-funded medical insurance have met with little success, ${ }^{4}$ and family policy has done little to mitigate Russia's high abortion rate. The continuous defeat of anti-abortion bills points to a current preference in the Duma for a more moderate execution of family policy than either the church leadership or conservative politicians support. The moderate abortion laws currently in place reveal the limitations of church influence on state pronatalist policy, which is almost entirely based in financial incentives for women to increase birthrates while lacking substantive barriers to alternate reproductive choices.

Further complicating the issue is the fact that the maternity capital program presupposes, but provides limited support for, the heteronormative familial arrangement that the church upholds as a matter of social policy (see Osnovy sotsial'noi kontseptsii 2000). As Borozdina et al. observe, despite commonalities with Soviet pronatalist policy, the state no longer actively promotes working motherhood - though, it should be noted, the reluctance to legislate against abortion and birth control does reflect some attention to its realities $(2016,62)$. Contemporary Russian authorities "appear to acknowledge that child care inevitably weakens women's position in the labor market," and offer a monetary compensation for this loss rather than working toward a reconciliation of the two roles (ibid.). Putin's 2006 statement that maternity capital was meant to help the "degraded housewife" is a prominent example of this discursive reliance on a theoretical two-parent family with a male breadwinner. However, the family as a unit is not at the forefront of federal pronatalist discourse or substantive policy.

While maternity capital has been "interpreted as part of a strengthened paternalist attitude in family and gender policies and a statist welfare model" (Chernova 2010, 2011; Kashina and Iukina 2009), the monetary benefit "coexists with state neglect in the development of social services for families with children" (Borozina et al. 2016, 61). Contemporary Russian policies "pay little attention to the reconciliation of work and family," as shown, for example, in the shortage of pre-school

4. Most recently, Senator Elena Mizulina spearheaded a group of deputies who introduced a bill to both exclude abortion from insurance and to fine private abortion providers ("Mizulinoi pomeshali" 2017). 
and daycare institutions, and are not concerned with facilitating family life (Chernova 2012, 82; Borozdina et al. 2016, 61). ${ }^{5}$ Most tellingly, "maternity capital," as a policy, is aimed at mothers rather than families, with fathers receiving access to management of the grant only in outstanding cases (Borozdina et al. 2016, 63).

Pronatalist policy, rather than a manifestation of substantive Orthodox influence, is primarily a "numbers game" aimed at increasing the birthrate by deploying church teachings where convenient. Though the focus on the woman as the natural care provider is certainly a reflection of gender traditionalism, substantive support for a paternal policy that would make workable a "traditional" domestic model is notably absent. Ultimately, the celebration of the Day of Family is one of the few components of state pronatalism that centers the family and the spousal relationship.

\section{Theorizing Contemporary Russian Pronatalism: Gender and Traditionalism}

If the reality of pronatalist policy decenters the heteronormative family and particularly marginalizes the husband and father, pronatalist ideology - expressed as it is most frequently in the context of "traditional family values" - instead prioritizes the family unit. Particularly in the context of the Day of Family, Love, and Fidelity, but also in the administration of ceremonial and optical aspects of family policy such as the Order of Parental Glory, pronatalist discourse draws superficially on Orthodox matrimonial theology in its construction of the "traditionalist" post-Soviet "gender order" (Connell 1987). ${ }^{6}$ While the existing gender order does not fully reflect the ideals of pronatalist ideology, it is based on the same "traditional" gender hierarchy; indeed, the existing cultural standard supporting a strict gender-based division of labor ${ }^{7}$ serves as the foundation of traditionalist pronatalist rhetoric (Shadrina 2017, 164). Pronatalist ideology is aimed at re-

5. It might be argued, of course, that the slow expansion of such facilities is a strategy to keep mothers at home, but this is merely conjecture.

6. A "gender order" is made up of "gender regimes," or "gender-based institutionalized power relations which allocate men and women to different social tasks and characterize specific institutions"; particularly, in this case, the gender regime of the heteronormative family (Charlebois 2011, 24).

7. According to the aforementioned study from Tomilin et al., 40 percent of respondents indicated that a man must be the head of the family, while less than 1.5 percent agreed that a woman could play that role (Tomilin et al. 2014). 
fining and strengthening current patriarchal gender regimes and the prevention of liberalization in gender relations.

Examining pronatalist ideology through the lens of gender constructivism, which examines gender as a "society-wide institution that regulates people's lives" and a "powerful ideological device which produces, reproduces, and legitimates choices and limits," we observe that the traditionalist reshaping and ideological deployment of "femininity" and "masculinity" is central to pronatalism as both a state policy and a religious movement of social transformation (West and Zimmerman 1987, 147). A facet of gender constructivist theory particularly crucial for this analysis is the theoretical framework of "doing gender" (West and Zimmerman 1987), which centers the notion of "accountability"; that is, the self-regulation of gender behavior based on how it is socially perceived, a concept rooted in Judith Butler's understanding of gender performativity.

Gender, in this framework, is an active repeated accomplishment achieved by participating in "a complex of socially guided perceptual, interactional, and micro political activities that cast particular pursuits as expression of masculine and feminine "natures" (ibid., 126). As an accomplishment and something to be consistently maintained, gender is constantly subject to "slippage," particularly as a surplus of variant gender expressions arise in the post-Soviet space. In creating the Day of Family, Love, and Fidelity, the state is working to shape a neotraditionalist, heteronormative model of gender as the hegemonic norm, which must be continuously cited at the risk of deviation and marginalization. The long-term goal of the institutionalization of the holiday is that its gender ideology will become a genuine reflection, rather than an ideal, of the Russian gender order due to the increasing unavoidability of enacting those ideals as an integral aspect of one's gender conformity. The optics and ideology of the holiday act to continually model and reinforce appropriate gender performance.

The hierarchs of the Russian Orthodox Church have been "deeply involved in the debates on the role and place of traditional values in national identity of Russia's past and present" since the collapse of the Soviet Union, attributing to the church an "exclusive role in the sphere of culture and morality" (Stepanova 2015, 120). This role is bolstered by widespread trust ${ }^{8}$ in the church and support of, if not obedience to,

8. According to a 2016 poll conducted by the Levada Center, 43 percent rate the church as worthy of complete trust. http://www.levada.ru/2016/10/13/institutsionalnoe-doverie-2/. 
its social principles ${ }^{9}-$ posited as synonymous with traditional values - among the populace (ibid.). Moreover, the ascension of Putin correlates with a spike in Orthodox identity, particularly after the second election (2007-2008) (Zorkaia 2009, 65). It is for these reasons that pronatalist ideology and its optics depend heavily on the church. Although its moral guidance appears to have little influence on those who identify as Orthodox, the "institutionalization of traditionalist discourse" in contemporary Russian family policy has become a "fait accompli": the "ideology of state policy creates patriarchal gender relations, idealizes the traditional family model, and ascribes it the highest value" (Chernova 2012, 91).

Reinforcing the ideological rhetoric underpinning the 2006 "pronatalist turn" was Putin's 2012 address to the Federal Assembly explicitly calling for the government's support for "traditional values," which presupposes the reinforcement of the patriarchal gender hierarchy as a primary requisite for the growth of the Russian family (Shadrina 2017). Indeed, "traditional values" discourse, particularly since the early 2000s, has been focused almost exclusively on "restoring" the Russian family to its ostensibly "traditional" (pre-Soviet) form distinguished in part by a strict division of labor along gender lines. This discourse also delegitimizes liberal opposition to the dominant ideological, political, and legal regime, including advocacy for gender equality and female agency, as inherently "anti-Russian" and anti-Christian (Laruelle 2014, 1).

Traditional values discourse serves the wider goal of the "re-feminization" and "re-masculinization" of the populace. A key motivation here is the prevention of single motherhood and absent fatherhood through the promotion of male economic responsibility and female dependence. Where Western sociologists of fertility focus on transforming women's "double burden" of domestic labor and employment, Russian critiques of the status quo "envision empowering men with renewed familial authority" (Rivkin-Fish 2010, 721). With the erosion of

9. According to a 2014 study of the correlation between Orthodox identity and support for traditional family values based on the residents of the city of Tambov, while a majority (52.5 percent) of respondents expressed support of the mnogodetnaia sem'ia, only 40.8 percent expressed a theoretical desire for a third child and only if they had access to the best financial and social resources. The idea of sacrifice in favor of openness to the birth of many children has certainly not penetrated the belief system of any but the most devout Orthodox. Nevertheless, the majority of respondents agreed that Orthodox values had the potential to strengthen the family, even as their answers demonstrate their personal divergence from those very Orthodox familial ideals. Respondents described the positive influence of the church on their family in terms of mutual love and domestic tranquility rather than the inspiration to change their reproductive habits (Tomilin et al. 2014, 192). 
social benefits and the redefinition of motherhood as a "private institution and responsibility," men are "expected to reassume the traditional 'male' responsibilities which have now been abandoned by the state" (Ashwin 2000, 2).

Church and state gender ideologies posit as necessary not only the reinforcement of the already strong social association between femininity and motherhood, but also the strengthening of the significantly weaker association between masculinity and fatherhood. Mnogodetnost' (having multiple children) is necessarily contingent upon a familial and subordinate femininity that is reliant upon both maternity capital and spousal support, and its institution as a norm requires the acceptance of neotraditional subordination to both the husband and the patriarchal state as a necessary facet of femininity. However, the ideal of the husband and father remains somewhat ill-defined, and becomes subsumed in what Messerschmidt calls "non-hegemonic dominant masculinity," which presents a significant barrier to the aforementioned project of "masculinization"/"feminization" (2010).

Hegemonic masculinity (and femininity) refers to "the configuration of gender practice which embodies the currently accepted answer to the problem of the legitimacy of patriarchy, which guarantees (or is taken to guarantee) the dominant position of men and the subordination of women" (Connell 1995, 77). According to Messerschmidt, alongside hegemonic masculinity, there exist in every society "nonhegemonic dominant masculinities" (38) that demonstrate the "discrepancy between hegemonic masculinities and men's actual embodied gendered actions" (Charlebois 2011, 27). Dominant masculinities are the most powerful and widespread in a society, even if they do not correspond with the hegemonic masculinity deployed as a social norm. Here the masculine ideal is almost uniformly defined by ethnic "Russianness" and Russian Orthodox identity, oriented toward work and provision for familial needs, centered in the home, and avoidant of alcohol and promiscuity. This is an ideal that clashes with "nonhegemonic dominant masculinity," which is hard-drinking, aggressive, and promiscuous, and places little value on fatherhood (see Utrata 2015)..$^{10}$

Within a culture of masculinity that does not associate manhood with marriage and fidelity, the modest, chaste, devout St. Peter represents a "hard sell" as an aspirational model (as well as an insufficient model of

10. The men interviewed in Jennifer Utrata's 2015 study "Women Without Men: Single Mothers and Family Change in the New Russia" reinforce perceptions of Russian men as irresponsible, immature, and unsuited to monogamy and family life as normative. 
a fecund and dominant father and husband), just as the childless Fevronia ${ }^{11}$ makes little sense as a model for the "mother of many" (mnogodetnaia mat'). The "traditional family" faces the challenge of the unruliness of non-hegemonic masculinity that the provision of saintly models appears powerless to contain, given that hegemonic femininity and masculinity constitute unstable categories in the hagiography. While the church has increasingly focused on filling the gap in the guidance and support of fathers as heads of the Christian household in the last twenty years through specialized lectures and seminars, the extremely limited audience of "active" faithful results in the low effectiveness of such programs, leaving only Peter and Fevronia Day as the church's opportunity to reach a greater portion of the populace (Pablina 2010, 131).

Following the 2006 pronatalist turn, "traditionalism" became the foundation for the formation of a new national identity based on the distinguishing of the Russian subject from the "Western" based in part on heteronormative sexuality (Muraveva 2014, 68-86). In keeping with the nationalist underpinnings of Russian Orthodox identity, state pronatalist ideology relies on the appeal to popular perceptions of Russia as the global guardian of traditional family values, which are assumed to encompass mnogodetnost'. Most useful to the alarmist nature of pronatalist ideology is the church's claim that the rejection of traditional values "leads to the destruction of human beings and society"; for example, the shrinking family that has resulted from the decline of familial gender hierarchy (121). Thus traditional values discourse serves a wider goal of instilling, especially among the youth, particular gender norms stressing "traditional" heteronormative patriarchy.

\section{Pronatalism in the Ideologies of Church and State: Di- vergent Ideals}

The key role that Russian Orthodox hierarchs play in the Day of Family - as well as the symbolism of the holiday and its reliance on Orthodox iconography - is demonstrative of the way in which the pronatalist agenda targets ethnic Russians who identify as Orthodox rather

11. Fevronia, in particular, slips from the pronatalist feminine norm by fulfilling instead the Christlike norm of rejecting the female body that is inherent to her embrace of monasticism. Particularly in Orthodox hagiography, as Ashley Purpura explores in her article on "Hymnographic Constructions of Eastern Orthodox Gender Identities," female saints are "depicted as holy through the acquisition of masculine traits" $(2017,528)$. Femininity, therefore, is something mutable, which can be "put on and taken off," while masculinity is "less fluid and transfigured through realizing masculinity in Christological imitation (ibid., 528). 
than Russians (Rossian'e) as a whole, constituting a populist ${ }^{12}$ strategy rather than the policy of an Orthodox state. It is clear that the church does not ultimately set the agenda of the holiday, any more than it determines Russian family policy, nor does the church determine the method whereby the holiday is celebrated. The Day of Family thus represents one (albeit major) aspect of Russian state family policy rather than its encapsulation.

In promoting the heteronormative family, pronatalist rhetoric encourages an active, purposeful, patriotically minded repopulation of Russia that does not fully coalesce with the Orthodox theology of matrimony, even as many leaders of the church have sought to minimize this tension. While in its public activism the church represents "conservative" social policy in its condemnation of all forms of abortion and birth control and the encouragement of the prioritization of early marriage and motherhood in women's lives - Archpriest Dmitri Smirnov is perhaps the most vocal advocate of "patriotically minded reproduction" - the idealized familial "gender regime" dominant in the church and propagated in sermons and literature aimed at the devout often emphasizes that parenthood makes up only one facet of pious family life and only one possible path of holiness for both men and women even in marriage. The ascetic, self-sacrificial model of Orthodox marriage deviates from the a pronatalist social agenda, which conceptualizes the heterosexual family almost exclusively as a reproductive unit, while at the same time affirming an approach to reproduction considered too extreme by the majority of legislators.

The public celebration of the Day of Family is intended to showcase the ideal Russian family. This is evident in the holiday's promotional materials as well as in the public ceremonies honoring lifelong monogamous parents of many in televised ceremonies. Although, as we have seen, family policy focuses heavily on aiding "deviant families" no proof of marriage is needed, certainly, to access maternity capi-

12. Natalia Zorkaia notes in her 2009 article that the growth in ethno-confessional (Russian Orthodox) identity following the collapse of the Soviet Union was, and continues to be, a reaction to the disappearance of Soviet identity, which had de-emphasized issues of national and ethnic identity. The growth of identification with Orthodoxy is the growth of identification with, and trust of, the institution of the church, a phenomenon that elucidates the reliance of pronatalist ideology on the dissemination of Orthodox matrimonial theology, as the state had begun to utilize the church as an instrument of legitimization in the Yeltsin era (68). Complicating this situation, however, is the fact that Orthodox identity is quite weakly correlated with religious faith; moreover, the majority of those whose Orthodox identity is a statement of faith (43-47 percent) are elderly - that is, beyond the concern of pronatalist politics (72). 
tal - single or cohabitating parents are not visible on this holiday. The spotlight here is on the idealized minority: the mnogodetnaia sem'ia (family with many children), defined as five to seven or more children, currently making up 7 percent of all Russian families - many of them clerical (Novikova 2012). What is even more notable than the invisibility of the "deviant," however, is that of long-term married couples without children. The saints are called upon to serve as models for the mnogodetnaia sem'ia to the general public while serving as models of ascetic piety in the context of Orthodox matrimonial theology.

In the most recent, and most transparent, effort of a segment of church clergy - most prominently, again, Archpriest Smirnov, as well as other church leaders including clergy from Murom - to support the transformation of Peter and Fevronia as patron saints of the mnogodetnaia sem'ia, the Patriarchate announced in late May 2018 that the church would work with the organization In the Family Circle to erect the first monument to the saints including three children. These children - Princes Yuri and Sviatoslav and Princess Evdokiia - are not mentioned in any redaction of Peter and Fevronia's hagiography, and their connection to the saints is a product of historical extrapolation in favor of serving the pronatalist ends of the Day of Family, the tenth anniversary of which the erection of the monument will celebrate. ${ }^{13}$

On the one hand, then, church spokesmen such as Patriarch Kirill, Metropolitan Hilarion, and Archpriest Smirnov consistently push the state to commit more fully to a pronatalist agenda, and as we have seen, anti-abortion activism ${ }^{14}$ is a major component of its social activity. Indeed, the church has been advocating for a more prominent place for itself in the national pro-family project since the early $2000 \mathrm{~s},{ }^{15}$ with publicly active clergy advocating for its role in the promotion of rising birthrates through the provision of "spiritual resources for reviving the family," as Metropolitan Kliment of Kaluga and Borov stated at

13. "V Moskve" 2018.

14. In recent years, the church has focused on building shelters for pregnant women, mothers, and children in crisis, with plans to install such shelters in every parish in Russia. These centers are aimed at preventing women from obtaining abortions because of financial need or difficult circumstances, as well as to provide material support.

15. A prominent example of this campaign is the Osnovy sotsial'noi kontseptsii Russkoi Pravoslavnoi Tserkvi, the result of a six-year effort from a Synodal working group formed in 1994 confirmed by the Bishops' Council in 2000. The document posits the church as the key to solving the crisis of the family, including high divorce rates as well as demographic decline. Osnovy warns of the dangers of de-emphasizing motherhood and fatherhood in favor of careerism and of the weakening bonds of parents and children - ills to which the church holds the solution (108). 
a church-sponsored forum on demographics in 2004 (San'kova 2015, 103). On the other hand, many clergymen resist the ideology of reproduction as the central function of marriage, focusing instead on the ascetic path of matrimony - the key principle, as we have seen, of the Tale of Peter and Fevronia. ${ }^{16}$ While clergy nearly always refer to the family as a unit of parents and children when speaking generally - for example, Kirill's September 2014 address to the forum "Mnogodetnaia sem'ia v budushchee chelovechestva," in which he described the family as "a man and woman living together, preserving fidelity, and raising children" - the church's practical teachings de-emphasize this last point as well as the patriarchal family structure that is so important to the state pronatalist ideology that the church upholds (San'kova 2015, 101). Likewise, while pronatalist ideology reinforces the association between womanhood and motherhood, clergy consistently argue against the idea that a woman must bear many children to be a good wife or a Christian.

This more complex attitude about marriage is at the center of an eightpart series of discussions (besedy) on marriage and family life held in November and December of 2017 and disseminated to the public through pravoslavie.ru. In these besedy, clergy (as well as a lay psychologist) confirm that children are not the aim of marriage, preach against romantic attachment, and offer sober assessments of family life. In one beseda, Archpriest Andrei Ovchinnikov takes a brutally honest tone in his discussion of raising a many children, warning his audience against absorbing the strain of church propaganda that tells couples to aim for maximum reproduction. Of course, each speaker emphasizes the imperative that each Christian remain open to many children and eschew contraception. Openness, however, is not quite the same as ideologically driven reproduction.

\section{Optics and Influence}

The midsummer celebrations of the Day of Family, Love and Fidelity draw large crowds, to which ample television and news media coverage during the week of July 8 attests. Covering the cities in chamomile flow-

16. I base this assessment on my review of official church statements and documents about marriage (e.g., "On the Canonical Aspects of Church Marriage" and publicly-available Synodal proceedings on the website of the Moscow Patriarchate), as well as articles published in major Orthodox publications (pravoslavie.ru, pravlife.org, and pravmir.ru, as well as mospat.ru, the website for the Department of External Church Relations, and patriarchia.ru), between 2008 and 2018. The video and transcripts of the December 2017 Besedy on the family, discussed herein, represent the most recent and most comprehensive example of the dominant contemporary teachings around marriage and family in the contemporary Russian Orthodox Church. 
ers - a symbol of the holiday and its native Russian roots - local governments hold concerts, art exhibitions, traditional balls and folk dances, family-friendly film screenings, and other events oriented toward social transformation, even if most treat them strictly as entertainment. The centerpiece of the holiday, both in "real time" and in terms of the dissemination of its ideals to the public through the media, is the massive concert held in Murom in honor of the holiday and televised nationally on July 8. The broadcast of the concert nationwide, and the widespread coverage of the event in state, church, and independent media for weeks leading up to and following the event, gives the impression that the Day of Family holds much greater importance in Russian society than it does in reality, including the usurpation of Valentine's Day. The broadcast, too, is likely part of a larger strategy to portray a more positive image of the family than the dramatized portrayals of familial strife dominating Russian television, following the observations of academic experts who have deemed contemporary mass media ${ }^{17}$ damaging to the goal of raising the birthrate (Novikova 2012, 266; Smirnova and Frolova 2011, ${ }^{18}$ 203). Still, despite the state's heavy sponsorship of, and participation in, the holiday - Dmitri and Svetlana Medvedev (a prominent anti-abortion advocate), for example, usually present medals to families - its putative ideals and carefully managed optics cannot be said to reflect substantive policy.

The concert is an optical smorgasbord of Russian Orthodox and nationalist discourse and imagery strategically arranged to amplify "traditional values." Couples who have been married for many years, and families with many children - recipients of the "Medal of Love and Fidelity" - are often invited on stage to provide viewers with a living image of the ideal. These awards were introduced in addition to the Order

17. In response to this concern, in 2009 the church founded the Synodal Informational Department (now called, after a number of internal changes, the Synodal Department for the Relationship of the Church with Society and Mass Media), through which organ it promotes - among many other things - traditional family values, for example through the production of documentaries about Peter and Fevronia or the celebration of the Day of Family, which are often shown on public television. The church also owns a number of radio and television stations, and print and web-based publications (Shirokov 124).

18. Smirnova and Frolova (2011) argue in their article "Crisis of the Family in the Media," an analysis of the role of media in the promotion of pronatalism, that material support for the family does not solve its most pressing problems. Government support for the family, they write, must include the strategic utilization of contemporary mass media, rather than the current reliance on traditional government propaganda - a category to which, I would argue, the Day of Family belongs (220). However, Smirnova and Frolova, like many academic scholars of the family, also advise a modernized approach and embrace of the changing nature of the family in place of the regressive ideology of traditional family values currently dominant in both state and non-state media (222). 
of Parental Glory, also established in 2008 for families with exceptionally high numbers of children, carrying on the tradition of Soviet "hero-mothers" and members of the "Order of Maternal Glory." To a large extent, as we have seen, the Peter and Fevronia awards constitute the Christianization of a patriotic pronatalism with a long tradition in Russia.

The pièce de résistance of the concert - a performance of Ilya Reznik's "Hymn to the Family" - makes plain the conflation of "traditional family values," "Russianness," and Orthodoxy. As pop stars, youth choirs, and dancers in folk dress jointly take the stage to close the concert with the hymn, they are surrounded by Russian flags and banners reading "The Day of the Family is OUR holiday." The words of Reznik's hymn are full of intertwined religious/nationalist language, such as the following verse: The family is a kingdom of great love / In it is faith, righteousness and strength / The family is the pillar of the government / Of my country, of my Russia." There is no mistaking the message: to be Russian is to live in a large, pious Orthodox family.

Nowhere is the largely symbolic role of the Orthodox Church in the practice of the veneration of Peter and Fevronia by singles and engaged couples more apparent than the increasingly popular trend of marrying on July 8, particularly in Murom, in order to insure good fortune and lifelong togetherness with the saints' blessing. Those who wish to marry on the Day of Family, however, have only the option of the civil ceremony, as the veneration of the Murom saints falls in the middle of a fast, and marriages are forbidden by canon law. In response to the popularity of marrying on Peter and Fevronia Day, the church has instituted an additional annual holiday venerating the saints - September 19, the day of the return of Peter's relics to Murom - as a day on which the faithful may marry in church. The popularity of weddings on July 8 highlights the widespread treatment of Peter and Fevronia Day as a Russian "Day of Lovers," with most celebrants understanding little of its religious underpinnings. The phenomenon of July 8th weddings is evidence of the fact that the holiday has thus far had little transformative effect on Russian society simply because few have paid any more than the most cursory degree of attention to it, and even then only in terms of their own perception of what a holiday in celebration of love might entail.

\section{Conclusion}

In creating the federal holiday of Family, Love and Fidelity, the Russian government has not instituted a nationwide, state-sponsored celebration of an Orthodox saints' day, even as the symbolism and "national" origins 
of the holiday are key to its role in disseminating an ideology of a "return" to traditional Russian family values explicitly shaped by the church. Rather, the state has created a holiday that draws on the theological underpinnings and ecclesiastical understanding of marriage and family to promote a gender order that does not quite cohere with the order to be found in the narrative of Peter and Fevronia due to a clash of ideals visà-vis the reproductive goals of married couples, as well as representing an ideal that is not reflected in actual state family policy. As I discuss throughout this paper, the heteronormative gender order that the government deploys in its project of social transformation via the celebration of the Day of Family marginalizes and marks as deviant all those who do not live in nuclear family units with married parents and several children.

While the Tale of Peter and Fevronia reinforces the importance of monogamy and lifelong devotion crucial to the state's battle against high divorce rates, it falls short of serving as the pronatalist fable that state propaganda seeks to make of it when, for example, it creates medals for parents of seven or more children emblazoned with images of the childless saints to be publicly awarded on the Day of Family. At the same time, while projections of pronatalist ideology onto the Tale of Peter and Fevronia prove problematic when read in the context of church family theology and hagiographic exegesis, which emphasizes marriage as an ascetic school of love to which children are not central but even to an extent tangential, the hierarchy of the church has been vocal in its evaluation of the insufficiency of the holiday as a symbolic commitment to the resurrection of the traditional Russian family given the state's simultaneous support of abortion.

Key to this conflict, of course, is the way in which the similar but divergent "gender regimes" of church and state shape the ideal of the post-Soviet Russian woman. Where she is not, in the eyes of the church, seen exclusively or even most importantly as a mother - it is her path of salvation, either in marriage or in monasticism, that is prioritized, as indeed the Tale of Peter and Fevronia shows, de-emphasizing even her gender in favor of her Christianity - she is, crucially, always open to childbirth when married, and if she is indeed a mother, the raising of many children is conceptualized as a key element of her salvific matrimonial journey.

State pronatalist ideology, however, deploys an ideal of the Russian woman, mother, and worker based on the support of maternity capital and the acknowledgment of the economic sacrifices involved in motherhood, even if it cannot be said to promote equality in the workplace or careerism among women and if it encourages men to take on the 
chief role in supporting the family. By the same token, in affirming the social role of the contemporary Russian woman as a worker even if she is - ideally - a mother before all else, the state also tempers the extreme pronatalism exhibited in the spectacles honoring parents of many by providing a second, more practical ideal (the three-child family) existing beneath the veneer of a campaign for compulsory family growth.

It is perhaps the existence of this second, less ambitious ideal supported by state policies such as maternity capital - an ideal that does not demand the radical lifestyle shift of the church's ascetic marriage path or complete openness to unlimited reproduction - that helps explain why nearly a decade of the celebration of the Day of Family, Love, and Fidelity has yielded neither a significant increase in birthrate nor an abandonment of the celebration of Valentine's Day and its "foreign" romantic ideals among the Russian populace. While the state deploys aspects of Russian Orthodox matrimonial teachings to promote traditional family values, the church largely serves as the emblem of the specifically "native" Russian roots of the family values movement. Meanwhile, its teachings are subtly manipulated in order to support patently statist goals based on a contemporary gender order that simultaneously locates the woman in the workplace and the home, granting her a level of reproductive and matrimonial autonomy that clashes with the church's model for the family.

\section{References}

Ashwin, Sarah. 200o. Introduction to Gender, State, and Society in Soviet and Post-Soviet Russia, edited by Sarah Ashwin, 1-29. New York: Routledge.

Borozdina, Ekaterina, Anna Rotkirch, Anna Temkina, and Elena Zdravomyslova. 2016. "Using Maternity Capital: Citizen Distrust of Russian Family Policy.” European Journal of Women's Studies 23(1): 60-75.

Cameron, Deborah, and Don Kulick. 2003. Language and Sexuality. Cambridge: Cambridge University Press.

Charlebois, Justin. 2011. Gender and the Construction of Hegemonic and Oppositional Femininities. Minneapolis: Lexington Books.

Chausov, Aleksandr. 2018. "Versiia o sviazi sviatogo Valentina s gei-brakami imeet nekotoroe osnovania" [The story about the connection between St. Valentine and gay marriage has some foundation]. Vzgliad. February 14. https://vz.ru/society/2018/2/14/908273.html.

Chernova, Zhanna. 2010. “Demograficheskii rezerv: Molodaia sem’ia kak ob”ekt gosudarstvennoi politiki. [Demographic reserve: The young family as an object of government politics.] Zhenshchina $v$ rosskiiskom obschestve, no. 2: 26-38.

---. 2011. Semeinaia politika sovremennoi Rossii: Gendernyi analiz i otsenka effektivnosti [Family politics of modern Russia: Gender analysis and an evaluation of effectiveness]. Zhenshchina $v$ rosskiiskom obschestve, no. 3: 44-51. 
-_-. 2012. "New Pronatalism? Family Policy in Post-Soviet Russia.” Region 1(1): 75-92.

Connell, Raewyn W. Gender and Power: Society, the Person and Sexual Politics. Cambridge: Polity Press, 1987.

Connell, R. W., and James W. Messerschmidt. 2005. "Hegemonic Masculinity: Rethinking the Concept." Gender \& Society 19(6): 829-59.

Demkova, N. S. 1997. "K interpritatsii 'Povesti o Petre i Fevronii': 'Povest o Petre i Fevronii’ Ermolaia-Erazma kak pritcha” [Towards an interpretation of the "Tale of Peter and Fevronia": "The Tale of Peter and Fevronia" of Ermolai-Erasmus as a parable]. St. Petersburg: Srednevekovaia literatura.

Federal State Statistics Service. 2017. The Demographic Yearbook of Russia: Official Publication. Moscow.

Gribble, Lyubomira Parpulova. 1995. “'Zhitie Petra i Fevronii’: A Love Story or an Apologia of Marriage?" Russian Language Journal/Russkii iazyk 49(162-64): 91113.

Kashina, M., and I. Iukina. 2009. Rossiiskaia demograficheskaia politika: Opyt gendernogo analiza [Russian demographic politics: A gender analysis. Zhurnal sotsiologii i sotsialnoi antropologii 12(1): 109-23.

Kim, N. V. 2017. "Zhenshchina v sem'ie: Representatsiia semeinoi politiki v rossiiskikh SMI do i posle 2006 g." [The woman in the family: The representation of family politics in Russian mass media before and after 2006]. Zhenshchina $v$ rossiiskom obschestve 1(82): 64-74.

Laruelle, Marlene. 2014. “Beyond Anti-Westernism: The Kremlim's Narrative about Russia's European Identity and Mission. PONARS Eurasia Policy Memo, no. 326.

Levada Center. 2016. "Institutsional'noe doverie" [Institutional trust]. October. https:// www.levada.ru/2016/10/13/institutsionalnoe-doverie-2/print/.

Messerschmidt, James W. 2010. Hegemonic Masculinities and Camouflaged Politics: Unmasking the Bush Dynasty and Its War against Iraq. Boulder, CO: Paradigm.

Milonov, Vitalii. 2017. “Den' sem'i - eto ne den' vliublennykh” [The day of family is not a day of lovers]. Interview with Govorit Moskva. July 18. https://govoritmoskva.ru/ news/126869/

"Mizulinoi pomeshali vyvesti aborty iz sistemy OMS" [Mizulina is prevented from removing abortion from OMS system]. 2017. Lenta.ru. October 26. https://lenta.ru/ news/2017/10/26/abort_oms/.

Muraveva, Marianna. 2014. ““(Ne)traditsionnye seksual'nye otnosheniia' kak iuridicheskaia kategoriia: Istoriko-pravovoi analiz" ["Non-traditional sexual relations” as a juridical category: A historical-legal analysis]. In Na pereput'e: Metodologiia, teoriia $i$ praktika LGBT i kvir-issledovanii, 68-86. St. Petersburg: Tsentr nezavisimykh sotsiologicheskikh issledovanii.

Novikova, E. S. 2012. "O vlianii SMI na reproduktivnye ustanovki" [On the influence of mass media on reproductive attitudes]. In Kommunikativnye strategii informatsionnogo obshchestva: Trudy V Mezhdunarodnoi nauchno-teoreticheskoi konferentsii, 266-67. St. Petersburg: Izd. Politekhnicheskogo universiteta.

"O kanonicheskikh aspektakh tserkovnogo braka" [On the canonical aspects of church marriage]. 2017. Patriarchia.ru. December 1. http://www.patriarchia.ru/db/ text/5075384.html.

Osnovy sotsial'noi kontseptsii Russkoi Pravoslavnoi Tserkvi [The basis of the social concept of the Russian Orthodox Church]. 2000. Otdel vneshnikh tserkovnykh svaizei [Department of External Church Relations]. https://mospat.ru/ru/documents/social-concepts/. 
Pablina, A. S. 2010. "Russkaia pravoslavnaia tserkov' kak sub”ekt sotsial'noi zashchity sem'i” [The Russian Orthodox Church as an agent in the social protection of the family]. Vestnik Mordovskogo Universiteta, no. 2: 129-33.

Pervozvanskii, Maksim. 2017. "Vybor sputnik zhizni” [Choosing a life partner]. Pravoslavie. ru. 25 November. http://www.pravoslavie.ru/108755.html.

Purpura, Ashley. 2017. "Beyond the Binary: Hymnographic Constructions of Eastern Orthodox Gender Identities.” The Journal of Religion 97(4): 524-46.

Rivkin-Fish, Michele. 2010. "Pronatalism, Gender Politics, and the Renewal of Family Support in Russia: Toward a Feminist Anthropology of 'Maternity Capital.” Slavic Review 69(3): 701-24.

San'kova, Vera. 2015. "Rol' Russkoi Pravoslavnoi Tserkvi kak khranitel'tsi fundamental'nykh tsennostei rossiiskoi sem'i" [The role of the Russian Orthodox Church as preserver of the fundamental values of the Russian family]. Zhurnal Samarskoi Dukhovnoi Seminarii 1(19): 101-5.

“S”ezd drevneishikh gorodov Rossii ‘otmenil’ den' Sv. Valentina” [Conference of ancient Russian cities have 'cancelled' St. Valentine’s Day”]. 2002. Ural.ru. August 5. http:// www.ural.ru/news/life/2002/o8/05/news-19872.html.

Shadrina, Anna. 2017. Dorogie Deti: Sokrashchenie rozhdaemosti i rost "tseny" materinstva $v$ XXI veke [Dear children: The reduction in fertility and the growth of the "value" of motherhood in the 21st century]. Moscow: Novoe literaturnoe obozrenie.

Shirokov, E.Iu. 2016. "Semeinaia Politika Russkoi pravoslavnoi tserkvi v kontekste ee sotsialnoi kontseptsii na primere rosskiiskoi federatsii” [The Russian Orthodox Church's family policy in the context of its Social Concept (on the example of the Russian Federation]. Vesnik BDU, Seriya 3, Gistoryia, Ekanomika, Prava, no. 3: 121-25.

Smirnov, Dmitrii. 2017. "Besedy s batiushkoi: S prot. Dmitriem Smirnovym" [Conversations with the priest: With Father Dmitrii Smirnov]. TV-Soyuz. September 17. http://tvsoyuz.ru/peredachi/besedy-s-batyushkoy-efir-ot-17-sentyabrya-2017g.

Smirnova, O. V., and T. I. Frolova. 2011. "Krizis sem'i v mediaizmereniiakh (analiz tekstov rosskiiskikh SMI)" [The crisis of the family in media evaluation (analysis of texts of Russian mass media)]. Vestnik Moskovskogo Universiteta, Seriia 10, Zhurnalistika, no. 1: 203-27.

Stepanova, Elena. 2015. "The Spiritual and Moral Foundation of Civilization in Every Nation for Thousands of Years': The Traditional Values Discourse in Russia.” Politics, Religion \& Ideology 16(2-3): 119-36.

Tomilin, Viktor F., Dina V. Belinskaia, Olga V. Averina. 2014. "Otsenka vlianiia pravoslavnykh tsennostei na sokhranenie sem'i” [Assessment of the influence of Orthodox values on the preservation of the family]. Vestnik Tambovskogo Universiteta 5(133): 189-97.

Tkachev, Andrei. 2016. "Propoved' o brake, vernosti, i liubvi" [Sermon on marriage, fidelity, and love]. July. https://www.youtube.com/watch?v=2hGFxyQEYdg

Utrata, Jennifer. 2015. Women without Men: Single Mothers and Family Change in the New Russia. Ithaca, NY: Cornell University Press.

"V Moskve ustanoviat pamiatnik sviatym Petru i Fevronii Muromskim" [Monument to Saints Peter and Fevronia of Murom to be erected in Moscow]. 2018. Patriarchia.ru. May 31. http://www.patriarchia.ru/db/text/5212907.html.

West, Candace, and Don H. Zimmerman. 1987. "Doing Gender." Gender and Society 1(2): 125-51.

Zorkaia, Natalia. 2009. "Pravoslavie v bezreligioznom obschestve" [Orthodoxy in a non-religious society]. Vestnik obshchestvennogo mneniia (2): 65-84. 